\title{
MEMBANGUN VISUAL STORYTELLING DENGAN KOMPOSISI DINAMIK PADA SINEMATOGRAFI FILM FIKSI "ASMARADANA"
}

\author{
Tri Adi Prasetyo \\ Dyah Arum Retnowati \\ Latief Rakhman Hakim \\ Jurusan Film \& Televisi, Fakultas Seni Media Rekam, Institut Seni Indonesia Yogyakarta \\ J1. Parangtritis km. 6.5 Yogyakarta Telp. (0274) 381047
}

\begin{abstract}
ABSTRAK
Karya tugas akhir penciptaan seni yang berjudul Membangun Visual Storytelling Dengan Komposisi Dinamik Pada Sinematografi Film Fiksi "Asmaradana" merupakan sebuah karya film pendek yang mengangkat kisah sepasang suami istri yang baru saja menikah. Konflik utama yang terjadi adalah tokoh Jaya selalu mengorbankan perasaan dan fisiknya demi bukti cinta kepada tokoh Ratih, tetapi justru Ratih mengalami atau menderita sebuah kelainan seksual.

Secara umum film dapat dibagi atas dua unsur pembentuk yakni, unsur naratif dan unsur sinematik. Di dalam unsur sinematik terbagi menjadi beberapa bagian yaitu sinematografi, mise-en-scene, editing, dan suara. Sinematografi dapat dikatakan sebagai menulis dengan cahaya ke dalam sebuah gerakan gambar, sehingga sangat bergantung serta berhubungan erat pada bidang fotografi.

Konsep estetik pada penciptaan karya seni film fiksi "Asmaradana" menggunakan komposisi dinamik sebagai media untuk membangun sebuah visual storytelling pada film fiksi. Visual Storytelling adalah penyampaian cerita secara naratif melalui urutan kejadiankejadian tertentu dengan menggunakan image- image visual atau grafik, baik bergerak maupun diam. Penggunaan komposisi dinamik pada sinematografi film fiksi "Asmaradana" bertujuan untuk menyampaikan ketidakharmonisan antar karakter tokoh cerita, melalui dominasi ukuran dan posisi objek utama pada penataan elemen-elemen visual komposisi gambar di dalam bidang sinematografi.
\end{abstract}

kata kunci : film, sinematografi, visual storytelling, komposisi dinamik

\section{Pendahuluan}

Manusia mempunyai kebutuhan untuk dicintai dan mencintai dalam menjalani kehidupan. Pembahasan mengenai cinta selalu menarik untuk digali, khususnya cinta eros. Cinta eros atau cinta erotis adalah cinta yang mendambakan suatu peleburan secara total dan penyatuan dengan pribadi lain dengan kata lain bahwa antar individu merasa saling mendominasi (Fromm, 2005:89). Film “Asmaradana” bercerita tentang sepasang suami istri (Jaya dan Ratih) yang baru saja menikah namun sosok sang istri mengalami kelainan biologis. Bentuk kelainan biologis yang dialami sosok istri adalah masokhis.

Kunci utama dalam penyampaian pesan pada film "Asmaradana", ditunjukan melalui ketidakseimbangan antar karakter tokoh yang terdapat pada visual storytelling. Visualisasi tersebut dicapai dengan menggunakan komposisi dinamik untuk memperkuat nilai estetik 
pada visual storytelling. Komposisi dinamik tidak mempunyai komposisi yang seimbang, ukuran, posisi, dan arah gerak objek sangat mempengaruhi kondisi gambar serta elemen-elemen visual pada komposisi dapat berubahubah secara dinamis. Penggunaan komposisi dinamik pada film "Asmaradana" ditunjukan dengan menunjukan suasana yang dialami oleh karakter utama serta bertujuan untuk menyampaikan ketidakharmonisan antar karakter tokoh melalui dominasi ukuran dan posisi objek utama di dalam penataan elemen-elemen visual pada komposisi gambar. Penjabaran informasi dan emosi cerita kepada penonton disampaikan dalam rangkaian shot. Pencapaian rangkaian shot tersebut dapat diwujudkan dalam bentuk visualisasi suasana tokoh melalui interpretasi sinematografer terhadap skenario atau naskah film yang kemudian diubah ke dalam bentuk gambar (visual) dengan menggunakan komposisi dinamik. Ilusi visual di dalam penataan komposisi dinamik dapat dipengaruhi oleh emosi, nuansa, suasana dan penataan tokoh di dalam adegan cerita pada pembingkaian komposisi gambar film "Asmaradana". Elemenelemen visual dalam komposisi dinamik tersebut menciptakan nilai estetis berdasarkan keseimbangan dan kesatuan dalam menyampaikan pesan serta suasana atau kondisi-kondisi yang dialami oleh karakter tokoh pada film Asmaradana.

Tujuan dan manfaat penggunaan komposisi dinamik dalam membangun visual storytelling pada penciptaan karya seni film "Asmaradana" terutama di bidang sinematografi meliputi, eksplorasi teknik komposisi sinematografi sebagai cara menyampaikan sebuah pesan yang terdapat pada film serta memberikan tambahan pengetahuan atau pengalaman khususnya mengenai teknik komposisi dalam bidang tata sinematografi sebuah film.

Salah satu hal yang paling penting pada cerita film yang berkaitan dengan proses membangun sebuah visual storytelling adalah metafora visual (visual metaphor) yaitu kemampuan gambar untuk menyampaikan makna cerita yang sebenarnya. Gambar yang bermakna adalah gambar yang setiap aspeknya memilikinilai emosional, simbol, dan pemaknaan konotasi, tidak ada aspek di dalam gambar yang terekam tanpa rencana. Setiap elemen, setiap warna, serta setiap bayangan memiliki tujuan tertentu untuk menyampaikan sebuah cerita (Brown, 2012: 68).

Elemen atau tools di dalam membangun sebuah visual storytelling melalui teknik sinematografi dibagi menjadi beberapa elemen (Blain, 2011:4): 
1. The frame atau pembingkaian komposisi gambar.

2. Pemilihan cahaya dan warna.

3. Pemilihan lensa.

4. Penggunaan pergerakan kamera.

5. Penambahan tekstur pada gambar.

6. Penggunaan establishing pada cerita.

7. Penggunaan point of view shot.

Pemilihan bingkai pada komposisi gambar merupakan hal paling mendasar dalam proses pembuatan sebuah film. Sinematografer harus mampu mengarahkan perhatian penonton terhadap cerita yang disampaikan melalui komposisi, ritme, dan perspektif (Blain, 2011:4). Komposisi yang baik merupakan aransemen dari unsur gambar untuk membentuk suatu kesatuan yang serasi atau harmonis secara keseluruhan. Elemen terpenting yang harus diperhatikan di dalam pembingkaian komposisi gambar adalah tingkat kecerahan (lighting), warna, ukuran, bentuk, gerak, kecepatan, dan arah. Melalui manipulasi terhadap unsur-unsur pembingkaian komposisi gambar tersebut dapat digunakan untuk mengarahkan perhatian penonton serta menciptakan respon emosional terhadap penonton (Mascelli, 2010:201).
Secara dasar komponen visual pada komposisi sinematografi dibagi menjadi 7 elemen dasar yaitu ruang, garis, bentuk, tone, warna, gerakan, dan irama (Block, 2008:2-10). Komponenkomponen visual dasar tersebut dapat ditemukan di setiap komposisi gambar bergerak maupun diam. Melalui penataan elemen- elemen komponen visual tersebut dapat mengomunikasikan suasana hati, emosi, ide serta memberi struktur visual pada komposisi gambar. Penataan elemen-elemen visual pada komposisi gambar dapat menghasilkan sebuah nilai kontras yang terdapat di dalam sebuah gambar atau menciptakan nilai dominasi pada gambar.

Setiap komponen visual dapat digambarkan serta digunakan di dalam mencapai tingkat kontras serta afinitas. Secara sederhana nilai kontras dapat diartikan dengan perbedaan, sedangkan nilai afinitas berarti sebuah kesamaan. Prinsip utama dalam menciptakan sebuah nilai kontras serta afinitas melalui komponen elemen visual tersebut terletak pada semakin besarnya tingkat kontras dalam komponen visual, semakin tinggi pula intensitas visualnya atau dapat menciptakan dinamisasi, sedangkan semakin besar afinitas dalam komponen visual, semakin kurang pula intensitas visual atau dinamisnya.

"The greater the contrast in a visual component, the more 
the visual intensity or dynamic increases. The greater the affinity in a visual component, the more the visual intensity or dynamic decreases. More simply stated: Contrast Greater Visual Intensity, Affinit Less Visual Intensity" (Block, 2008:11).

Ketika kamera mengambil gambar atau obyek, sutradara dapat memilih posisi obyek tersebut ke dalam frame sesuai tuntutan naratif serta estetik. Penata sinematografi bebas meletakan sebuah obyek dimana pun berada di dalam frame, di tengah, di pinggir, di atas, di bawah, sejauh komposisi gambar tersebut masih seimbang dan menyatu secara visual. Sebuah obyek tidak harus selalu berada di tengah frame untuk mencapai komposisi yang seimbang. Obyek lain di sekitar obyek utama mampu mempengaruhi komposisi dan sangat bergantung dengan posisi serta pergerakan obyek lain. Pengaturan posisi obyek di dalam pembingkaian komposisi gambar dapat digunakan penata sinematografi untuk mendapatkan motifmotif serta alasan tertentu yang dibuat secara sengaja, namun dengan pemikiran yang sudah matang. Beberapa penata sinematografi memiliki gaya yang khas di dalam mengatur komposisi visual. Secara umum komposisi gambar yang terkait dengan posisi obyek di dalam frame adalah Komposisi Dinamik (Pratista, 2008:115).

"Komposisi Dinamik sifatnya fleksibel dan posisi obyek dapat berubah sejalan dengan waktu. Komposisi dinamik tidak memiliki komposisi yang seimbang (simetris). Ukuran, posisi, arah gerak obyek sangat mempengaruhi komposisi dinamik. Satu cara yang paling mudah untuk mendapatkan komposisi dinamik adalah dengan menggunakan sebuah aturan yang dinamakan rule of thirds. Dalam rule of thirds, garis-garis imajiner membagi bidang gambar menjadi tiga bagian yang sama persis secara horizontal dan vertikal. Dari persimpangan garis-garis imajiner tersebut akan didapat empat buah titik simpang." (Pratista, 2008:115)

Rule of Third dimulai dengan membagi ukuran frame menjadi tiga bagian. Aturan pertiga tersebut bertujuan untuk mendapatkan titik awal perkiraan pada setiap pengelompokan komposisi dengan menempatkan titik persimpangan pada salah satu dari empat persimpangan garis interior. Aturan persimpangan tersebut adalah perpaduan secara sederhana untuk membingkai komposisi gambar (Blain, 2011:51).

"The rule of thirds starts by dividing the frame into thirds. The rule of thirds proposes that a useful approximate starting point for any compositional grouping is to place major points of interest in the scene on any of the four intersections of the interior lines. It is a simple but $e$ ective rough guideline for any frame composition. The rule of thirds has been used by artists for centuries." (Blain, 2011:51) 


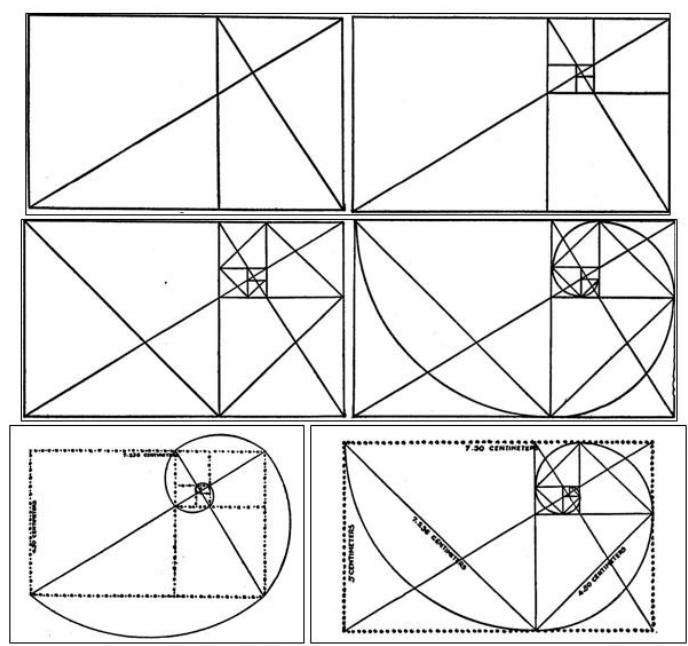

Gambar 1. Tahapan penentuan garis acuan the rule of thirds pada bingkai gambar. Sumber: Michael Jacobs, The Art Of Composition.

Komposisi terbaik dapat dicapai apabila posisi obyek utama terletak dekat dengan salah satu titik simpang tersebut. Pada umumnya objek visual diletakan pada garis perpotongan pertiga atas atau bawah dan sangat jarang meletakan pada posisi di tengah-tengah. Arah gerak dan arah pandang obyek juga dapat mempengaruhi komposisi dinamik (Pratista, 2008:115).

Proses pembingkaian pada komposisi dinamik gambar terdapat lima teknik untuk mendapatkan sebuah kedalaman komposisi gambar secara dinamis (No Film School, 5 Techniques That Create Depth and Make Your Cinematography More Dynamic) antara lain:

1. Penggunaan cahaya kontras.

2. Permainan fokus gambar.

3. Menentukan perspektif gambar.

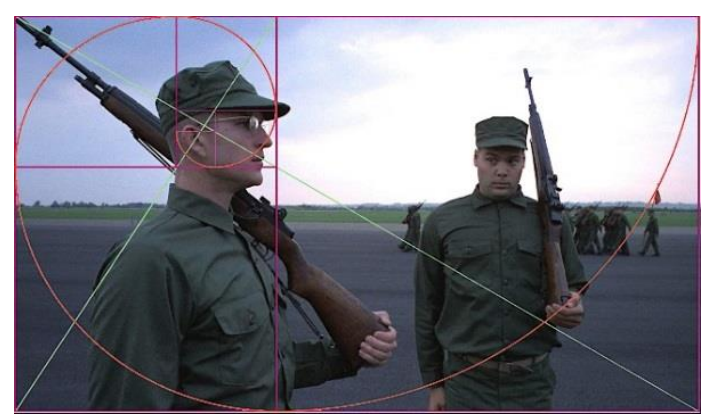

Gambar 2. Contoh penggunaan Golden Section pada komposisi gambar film Stanley Kubrick.Sumber:

Cinematography Composition history

4. Penggunaan paralaks atau pergerakan gambar.

5. Penambahan occlusion atau efek visual pada gambar.

Konsep estetik pada sinematografi film "Asmaradana" merupakan suatu konsep penciptaan yang berhubungan dengan rasa. Hal ini dapat dicapai melalui pemilihan ukuran gambar (shot size), penempatan angle kamera guna menempatkan sudut pandang penonton, penggunaan gaya tata cahaya dan penataan elemen-elemen visual ke dalam komposisi dinamik gambar yang bertujuan untuk membangun visual storytelling film secara maksimal, sehingga tercapai sebuah bahasa visual film yang baik serta memiliki nilai estetis. Tujuan dari penggunaan komposisi dinamik pada konsep sinematografi film "Asmaradana" adalah memberikan efek estetis gambar dan menciptakan sebuah alur cerita melalui rangkaian shot yang jelas serta menarik sehingga mudah dimengerti oleh penonton. Di dalam film "Asmaradana" komposisi dapat membuat suatu 
keseimbangan antara gambar dan cerita.

Pembentukan elemen-elemen visual pada komposisi gambar tersebut pada dasarnya bertujuan untuk membangun sebuah visual storytelling yang dicapai melalui simbolisasi suasana serta emosi yang dialami tokoh utama dengan menempatkan tokoh utama menjadi point of interest atau pusat perhatian, sehingga dapat memberikan kesan dominasi pada sebuah komposisi gambar. Rangkaian visual atau shot pada film "Asmaradana" dikonstruksi ke dalam pembentukan aspek-aspek komposisi dinamik yang dihadirkan melalui ketidakseimbangan dan ketidakharmonisan antar karakter tokoh.

Penggunaan komposisi dinamik pada sinematografi film "Asmaradana" digunakan pada scene-scene tertentu yang terdapat pada skenario dengan menggunakan beberapa teknik pengambilan gambar seperti penggunaan long take shot, penggunaan mobile framing atau pergerakan kamera dan beberapa penggunaan camera angle beserta level angle tertentu guna menyampaikan sudut pandang tokoh. Camera angle merupakan sebuah penempatan kamera yang akan memberi dampak terhadap sudut pandang penonton (Mascelli, 2010:5).

Komposisi gambar pada film "Asmaradana" menggunakan keseimbangan frame dinamik melalui penempatan elemen-elemen visual yang terdapat di dalam gambar. Komposisi dinamik tersebut menempatkan objek utama terhadap ruang gerak, memperlihatkan ruang atau setting, waktu dan peristiwa. Untuk mendapatkan komposisi dinamik yang baik pada film "Asmaradana", sinematografer menerapkan dan mengaplikasikan unsurunsur utama di dalam pembingkaian dengan menggunakan acuan The Rule of Third dan beberapa unsur pendukung komposisi sinematografi di dalam membingkai komposisi dinamik seperti penggunaan tata cahaya kontras, permainan fokus gambar, penggunaan perspektif pada gambar, pergerakan kamera dalam menangkap peristiwa (adegan) serta penggunaan efek tertentu guna membangun emosi atau suasana yang dialami tokoh. Penggunaan rule of third dalam pembingkaian komposisi gambar pada film "Asmaradana" bertujuan untuk membangun proporsi gambar yang dinamis dengan menempatkan objek utama menjadi point of interest pada sebuah gambar. Penempatan objek utama tersebut berada pada titik perpotongan atau persinggungan garis horizontal dan vertical yang terdapat pada sebuah frame. Perpotongan garis tersebut menghasilkan sembilan area atau bidang yang dibagi melalui 2 garis horizontal dan 2 garis vertical. 

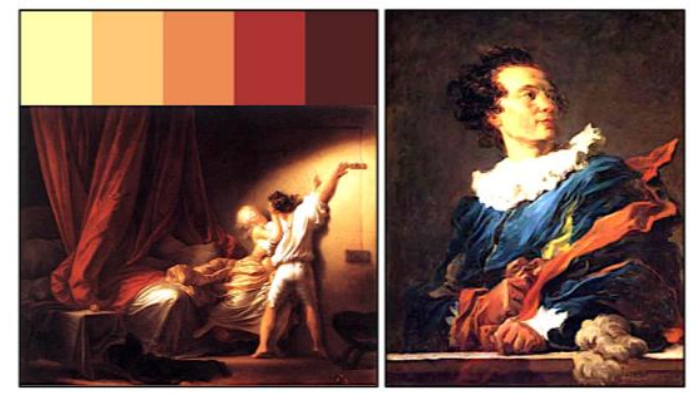

Gambar 3. Referensi warna dan color pallete pada lukisan Jean Honore Fragonard's.

Sumber: https://flic.kr/s/aHsjB7QwpQ (diakses 1 Maret 2018)
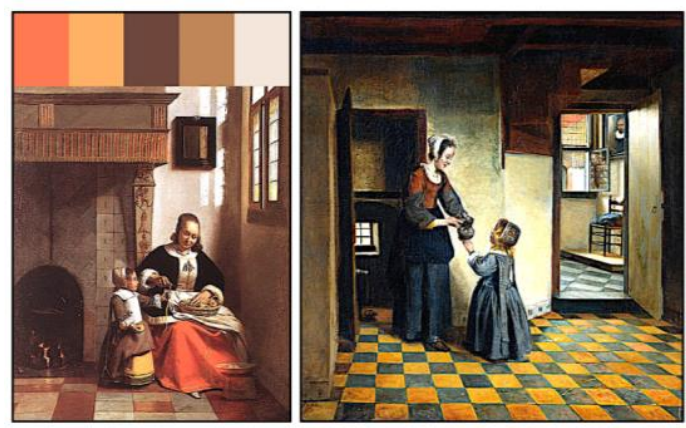

Gambar 4. Referensi warna dan color pallete pada lukisan Pieter De Hooch. Sumber: https://flic.kr/s/aHsjB1MqDA (diakses 1 Maret 2018)

Look dan Mood di dalam film "Asmaradana" dapat dicapai melalui pengolahan warna pada elemen-elemen visual pada pembingkaian komposisi dinamik. Warna mempunyai peranan penting dalam dunia fotografi dan sinematografi. Adanya asosiasi yang kuat dengan emosi, menjadikan warna pada suatu subjek memberikan energi dan menimbukan mood atau perasaan tertentu (Sugiarto, 2014:4). Melalui pemilihan warna dalam pembingkaian komposisi dinamik, sinematografer mampu mengungkapkan kepribadian tiap karakter tokoh pada film “Asmaradana". Elemen warna juga dapat menyeimbangkan emosi serta menciptakan keselarasan pada objek utama yang ditangkap oleh sensor kamera.

Warna yang digunakan pada film "Asmaradana" divisualisasikan dengan menggunakan warna-warna kontras dan natural tetapi tetap lembut bertujuan untuk membangun suasana serta emosi pada kedua tokoh pada film "Asmaradana". Penggunaan warna-warna primer panas pada film "Asmaradana" bertujuan untuk memberikan efek psikologis terhadap karakter tokoh sang istri yang terdapat pada film “Asmaradana”. Sedangkan penggunaan warna dingin akan diaplikasikan pada karakter tokoh sang suami yang memiliki kepribadian kaku dan tenang. Berikut gambaran mengenai referensi warna dan color pallete melalui referensi sebuah lukisan yang akan menjadi rujukan pada film "Asmaradana". Referensi warna pada rujukan lukisan di atas digunakan pada tiap tokoh di dalam film terutama pada tokoh Jaya dan Ratih. Penggunaan warna melalui rujukan lukisan tersebut dicocokan dengan elemen-elemen warna yang terdapat pada mise- en-scene terutama dalam pemilihan kostum pemain serta elemen property pada setting ruang kejadian. Pemilihan warna kostum pemain dipilih melalui motivasi karakter tokoh di dalam cerita serta makna psikologis warna yang terdapat pada referensi lukisan di atas. 


\section{Pembahasan Hasil Penciptaan}

Hasil awal penggabungan rangkaian shot pada film fiksi "Asmaradana" mencapai 38 menit. Rought cut pertama tersebut berisi seluruh adegan lengkap dengan struktur alur yang sesuai terhadap skenario film. Setelah mengalami berkali-kali pemotongan dan pembuangan scene, durasi film menjadi 24 menit dengan tetap menggunakan struktur alur linier. Picture lock film ini tidak mengurangi jalur cerita meski durasi dipersingkat. Tensi dramatik pada adegan yang dibangun melalui rangkaian shot justru lebih mudah dihidupkan dengan mempermainkan perpindahan shot di dalam tahap editing. Pembahasan karya dalam membangun visual storytelling film dapat dijabarkan melalui rangkaian shot. Di dalam setiap pembingkaian elemen-elemen visual komposisi gambar pada film "Asmaradana" memiliki tujuan tertentu untuk menyampaikan sebuah cerita. Berikut pembahasan visual storytelling dengan komposisi dinamik di setiap rangkaian shot sebagai berikut ini:

\section{Scene 1. EXT. KAMAR MANDI} - SIANG HARI

a. Shot 1. Medium Close UpRatih.

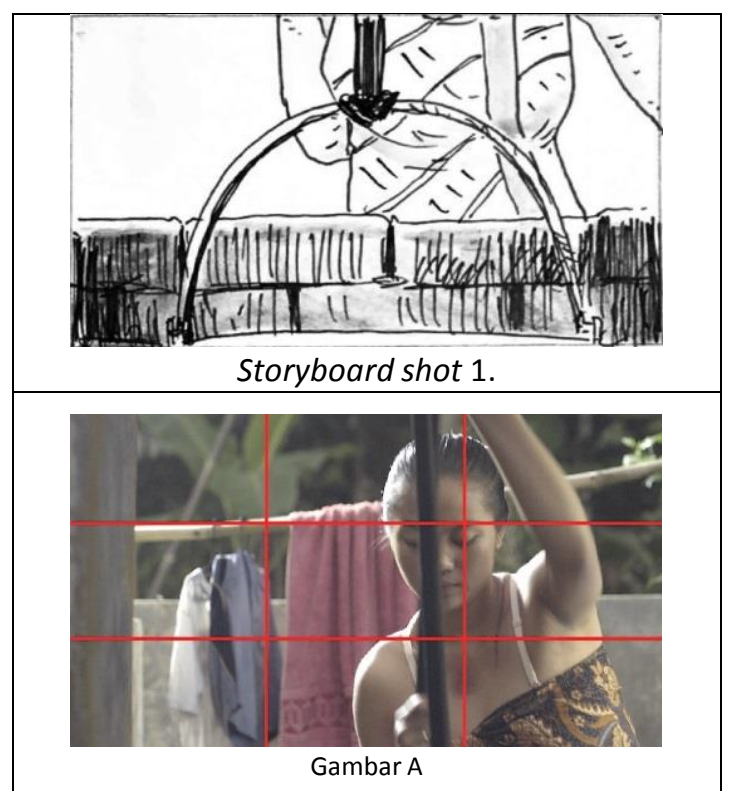

Gambar 5. Realisasi shot 1 pada Gambar A sebagai pengenalan Ratih berdasarkan storyboard di dalam scene 1.

Shot pertama dibuka dengan medium close up adegan Ratih yang sedang menarik timba air dari dalam sumur dan terlihat bagian tubuh Ratih terluka seperti luka sayatan. Shot ini merupakan tahap pengenalan tokoh Ratih seorang wanita yang hidup di desa divisualisasikan dengan adegan sedang menimba air di sebuah sumur tua. Penempatan angle objektif pada shot ini memposisikan penonton sebagai pengamat diluar peristiwa film yang mengamati aktivitas Ratih. Perspektif gambar yang digunakan shot 1 menempatkan objek utama pada bidang midground sehingga kedalam gambar dapat tercapai. Penempatan objek utama serta tanda bekas luka Ratih berada di sebelah kanan frame komposisi dinamik melalui acuan garis perpotongan yang bertujuan mengarahkan perhatian penonton ke dalam point of interest 
gambar (Blain, 2011:51). Elemen visual berupa bidang berwarna merah pada handuk ditempatkan pada background objek utama berdasarkan teknik perspektif gambar, sehingga menghasilkan sebuah keseimbangan gambar serta kedalaman gambar namun dominasi berada di posisi objek utama di bagian midground gambar (Blain, 2011:54).

Melalui pembingkaian komposisi dinamik dalam membangun visual storytelling film dapat diartikan bahwa shot 1 memberikan informasi kepada penonton perihal sosok seorang wanita misterius yang memiliki bekas luka sayatan di tubuhnya. Suasana kelam yang terdapat pada shot 1 dicapai melalui penggunaan cahaya kontras dalam menciptakan ilusi tiga dimensi melalui bayangan objek (Blain, 2011:44).

\section{b. Shot 2. Full Shot (Master Shot)} - Aktivitas Ratih.

Shot selanjutnya adalah adegan Ratih menuangkan air dari ember kecil menuju ember besar. Ada perubahan penempatan objek utama pada komposisi ini yang terlihat pada rancangan gambar storyboard dengan realisasi shot. Perbedaan tersebut ditunjukan dengan posisi blocking pemain yang awalnya berada di kiri frame pada rancangan storyboard menjadi berada sebelah kanan frame pada realisasi shot 2 .

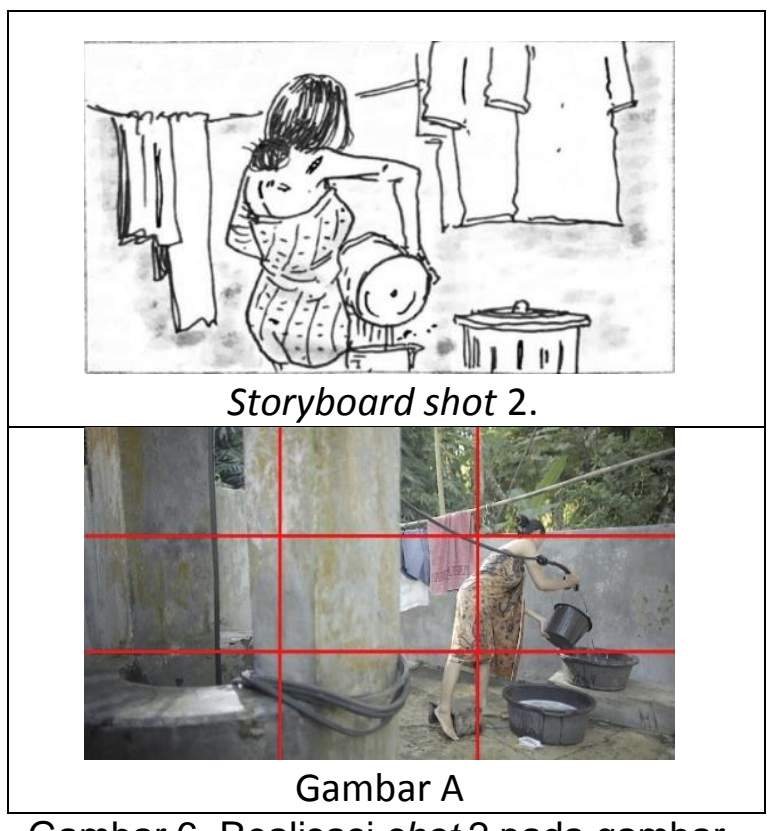

Gambar 6. Realisasi shot 2 pada gambar A berdasarkan storyboard di dalam scene 1

Tujuan perubahan penempatan objek utama pada komposisi gambar tersebut berfungsi untuk menjaga kontinuitas adegan dari shot sebelumnya yang dicapai melalui pengaturan posisi objek berdasarkan motif serta ukuran objek ke dalam komposisi gambar (Pratista, 2008:115). Kontinuitas adegan pada shot tersebut dicapai dengan menempatkan objek utama berada di sebelah kanan frame melalui acuan garis perpotongan. Penggunaan perspektif kedalaman gambar pada komposisi dinamik shot ini dicapai dengan menggunakan teknik deep focus. Bagian foreground memberikan informasi sebuah sumur tua sedangkan midground gambar diisi oleh objek utama dan background menampilkan suasana pagi hari.

Penjelasan melalui pembingkaian komposisi dinamik dalam membangun 
visual storytelling memberikan informasi suasana pagi dan aktivitas seorang wanita desa yang sedang menuangkan air ke dalam ember berada di sebuah kamar mandi yang masih memiliki sebuah sumur tua. Melalui penataan arah pandang objek utama yang mengarah ke kanan frame dapat diartikan sebuah penyempitan suasana serta rasa terperangkap yang dialami oleh tokoh Ratih di dalam cerita film.

c. Shot 3. Close Up - Aktivitas Ratih.

Shot ini merupakan lanjutan dari adegan Ratih yang sedang mencuci pakaian. Terdapat perbedaan antara storyboard dengan realisasi shot yang berada pada penempatan blocking pemain yang bertujuan untuk mendapatkan diskontinuitas pada adegan. Pemotongan gambar dengan menggunakan teknik jump cut digunakan pada shot ini bertujuan untuk memangkas durasi adegan yang terlalu lama. Penempatan objek utama ke dalam komposisi dinamik berada di kiri frame sengaja digunakan untuk memberikan sudut pandang kamera yang berbeda serta menciptakan disorientasi bagi penonton ketika memperhatikan aktivitas tokoh Ratih. Penggunaan teknik shallow focus pada shot ini bertujuan untuk mengarahkan perhatian penonton terhadap objek utama yang berada di kiri frame, sehingga penonton dapat memperhatikan detail ekspresi serta bekas luka di tubuh Ratih. Perspektif yang unik di dalam shot 3 membuat sebuah gambar tampak lebih kompleks dan dinamis (Blain, 2011:54).

Melalui komposisi dinamik dalam membangun visual storytelling mood yang muncul pada karakter Ratih berupa suasana kelam yang digambarkan melalui eksresi Ratih dan dicapai dengan penggunaan elemen cahaya kontras yang bertujuan membangun aspek-aspek dramatis pada karakter cerita (Blain, 2011:44). Pada shot 5 menggunakan ukuran shot size close up memberikan informasi kepada penonton untuk memperhatikan detail bekas luka pada tubuh Ratih dan detail pada aktivitas tokoh utama.

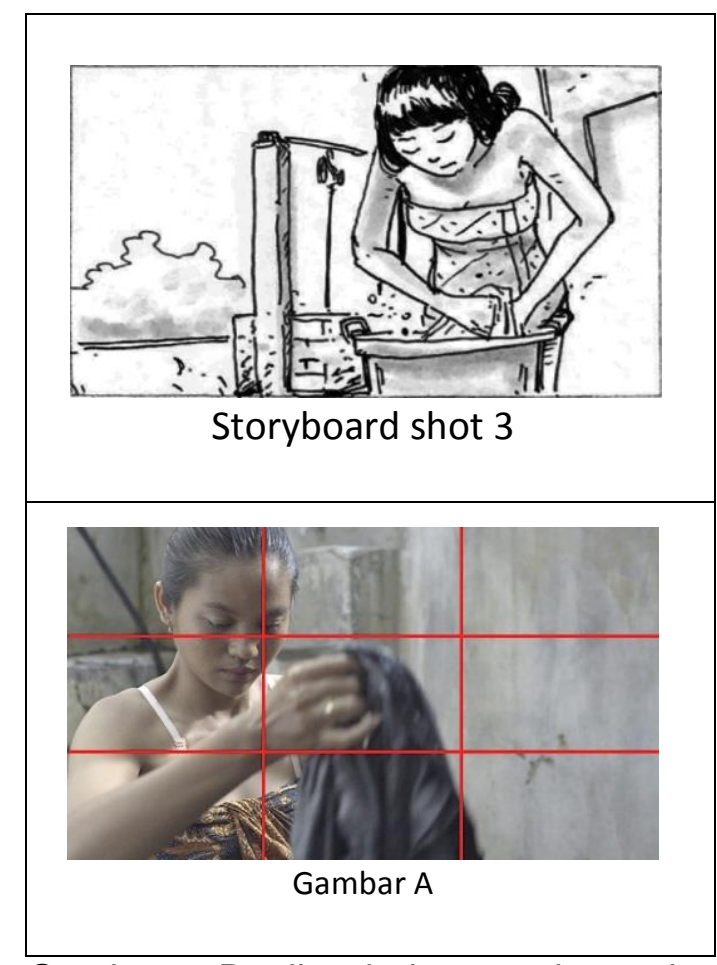

Gambar 7. Realisasi shot 3 pada gambar A berdasarkan storyboard di dalam scene 1. 


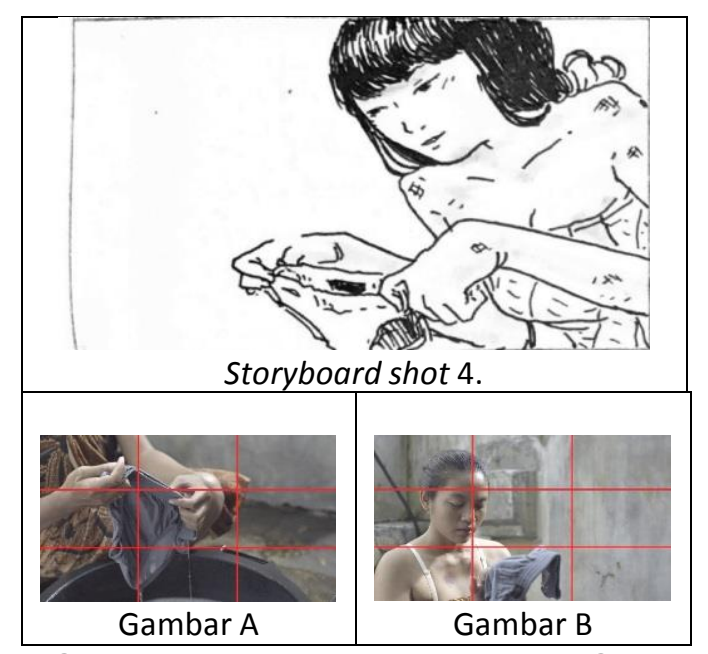

Gambar 8. Realisasi rangkaian Shot 4 pada Gambar A-B ekspresi Ratih berdasarkan storyboard shot 4 di dalam scene 1.

\section{d. Shot 4. Close Up (Match Cut) - Ekspresi Ratih.}

Shot selanjutnya merupakan lanjutan dari shot sebelumnya ketika ekspresi Ratih sedang memperhatikan dalam-dalam sebuah celana dalam pria yang berwarna abu-abu, lalu teringat ucapan ibunya ketika Ratih masih kecil. Tidak ada perbedaan dalam penempatan objek utama pada komposisi gambar namun penempatan elemen warna abuabu ditempatkan pada garis bawah komposisi dinamik. Perbedaan terlihat pada posisi blocking pemain pada rancangan storyboard dengan realisasi rangkaian shot 5 karena shot ini merupakan kontinutas dari shot sebelumnya.

Melalui pembingkaian komposisi dinamik dalam membangun visual storytelling pada rangkain shot 5 menggambaran suasana yang dialami tokoh Ratih yang dibangun melalui adegan serta elemen warna abu-abu pada celana dalam. Makna dari warna abu-abu tersebut bertujuan untuk membangun emosi yang dialami Ratih berupa sebuah kesedihan dan kerinduannya kepada sang Ibu. Elemen warna tersebut memberi keuntungan tambahan dalam mempengaruhi perasaan penonton serta membangun visual storytelling dalam pembingkaian komposisi gambar, sehingga penonton dapat menafsirkan cerita dengan cara yang berbeda- beda (Blain: 2011:8).

\section{Scene 4. INT. WARUNG KOPI- SIANG HARI}

a. Shot 3. Group Shot-Jaya, Sugeng dan Mira.

Shot berikut ini adalah master shot di dalam adegan scene 4. Pada shot 3 terlihat dominasi gambar yang berada pada objek utama tokoh Jaya dalam pembingkaian komposisi gambar. Penempatan objek utama pada komposisi dinamik berada di sebelah kanan frame dengan ukuran yang lebih besar dibanding kiri frame yang diisi oleh adegan Sugeng dan Mira. Tujuan dalam penggunaan dominasi gambar pada Gambar A adalah mengarahkan perhatian penonton pada tokoh utama Jaya yang merasa cuek melihat Sugeng dan Mira yang sedang bermesra-mesraan berada di salah satu titik persimpangan garis komposisi dinamik (Pratista, 2008:115). 


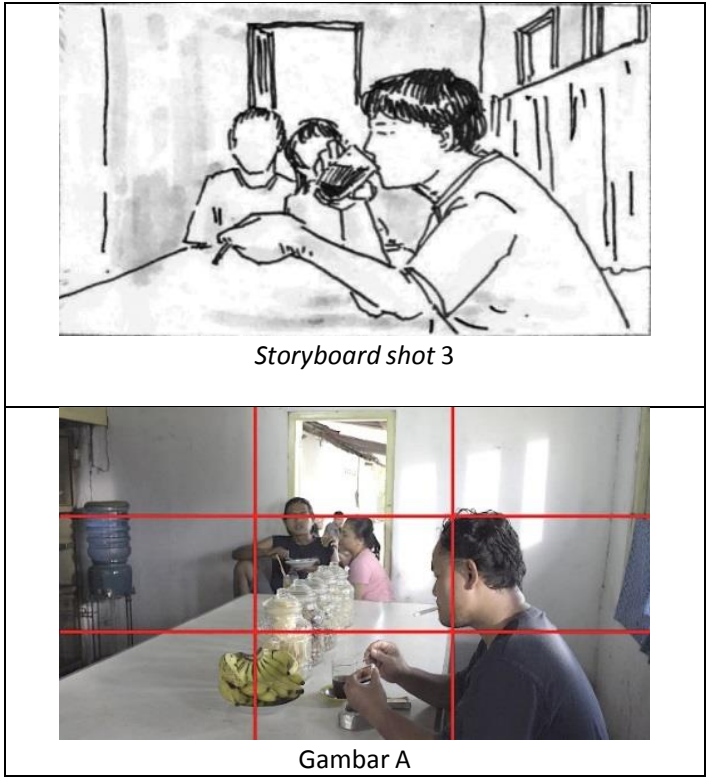

Gambar 9. Realisasi shot 3 pada Gambar A master shot berdasarkan storyboard di dalam scene 4.

Penggunaan teknik deep focus gambar pada perspektif komposisi gambar pun bertujuan untuk memberikan penonton dalam memilih arah pandangan utama serta mengidentifikasi adegan yang terdapat pada master shot namun dominasi gambar yang terasa pada komposisi dinamik gambar tetap berada pada foreground yang diisi oleh tokoh Jaya. Pada penataan cahaya di dalam scene 4 ini, penggunaan tata cahaya kontras di aplikasikan guna membangun look dan mood yang dirasakan oleh karakter tokoh utama, sehingga aspek dramatis dapat dicapai guna membangun suasana yang pada tokoh Jaya (Blain, 2011:44).

Suasana dan emosi yang dirasa dingin pada karakter Jaya dapat ditunjukan melalui dominasi gambar pada tokoh Jaya. Emosi yang dirasakan Jaya pada adegan tersebut adalah sikap 214 cueknya melihat Sugeng dan Mira yang bermesra-mesraan.

$$
\begin{aligned}
& \text { b. Shot 4. Two Shot - Jaya } \\
& \text { dan Mira. }
\end{aligned}
$$

Shot terakhir dalam pembingkaian adegan pada scene 4 terlihat tokoh Mira yang datang mendekati dan merayu tokoh utama Jaya. Penempatan objek utama pada pembingkaian komposisi dinamik berada seimbang kiri dan kanan frame melalui garis perpotongan gambar namun pada bagian kanan frame yang menjadi background terlihat elemen warna biru yang mewakili emosi dari tokoh Jaya. Penggunaan teknik shallow focus pada pembingkaian komposisi dinamik juga diaplikasikan ke dalam frame untuk mengarahkan perhatian penonton menuju tokoh Mira yang terlihat lebih detail dibanding tokoh Jaya.

Bahasa visual yang disampaikan melalui penataan komposisi dinamik gambar pada shot 4, membentuk dominasi gambar dalam penekanan adegan terhadap tokoh Mira yang mencoba merayu tokoh Jaya.

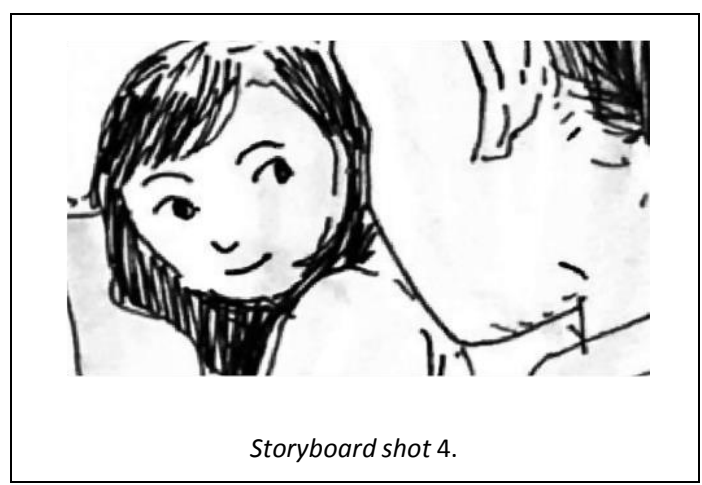




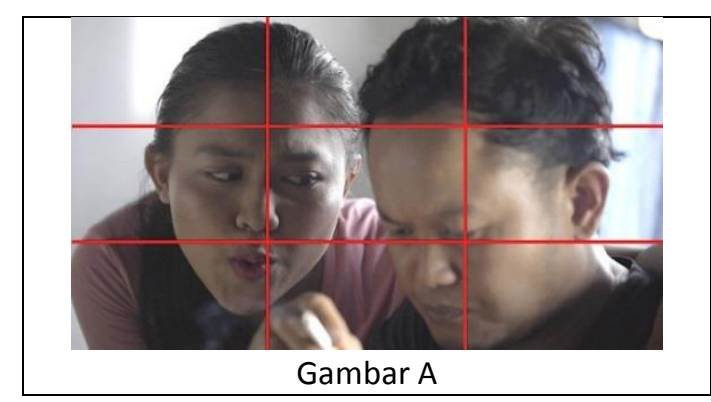

Gambar 10. Realisasi shot 4 pada Gambar A adegan Mira merayu Jaya berdasarkan storyboard scene 4 .

\section{Scene 7. INT. DAPUR RUMAH - SIANG HARI}

a. Shot 1. Two Shot (Master Shot) - Ibu dan Ratih Kecil.

Scene 7 merupakan adegan flashback Ratih kecil mendatangi ibunya yang sedang memasak di dapur rumah. Suasana di dalam scene ini divisualisasikan melalui penataan cahaya chiaroscuro dan penggunakan teknik occlusion (efek visual) pada pembingkaian komposisi dinamik gambar. Teknik chiaroscuro tersebut menerapkan nilai atau intensitas cahaya ke dalam dua dimensi gambar guna menciptakan ilusi menjadi bentuk tiga dimensi dengan bayangan atau shading (Blain, 2011:44). Penempatan efek cahaya tersebut berada hampir menyeluruh di dalam frame sehingga dominasi terbentuk melalui penataan cahaya. Tujuan penggunaan efek tersebut adalah untuk memberi informasi ruang dan waktu yang berbeda di dalam miseen-scene, sehingga teknik atmospheric perspective dalam pembingkaian komposisi dinamik tercapai dengan menekankan pada situasi yang dialami karakter tokoh Ibu dan Ratih pada cerita. Atmospheric perspective adalah Xketika objek diambil dari jarak yang jauh sehingga detail pada objek tersebut terlihat seperti kehilangan warna bahkan tidak jelas, perspektif ini dapat diciptakan melalui penambahan efek khusus seperti efek asap (Blain, 2011:44-45). Tujuan menggunakan teknik ini adalah untuk membedakan suasana ruang dan waktu terhadap scene 8.
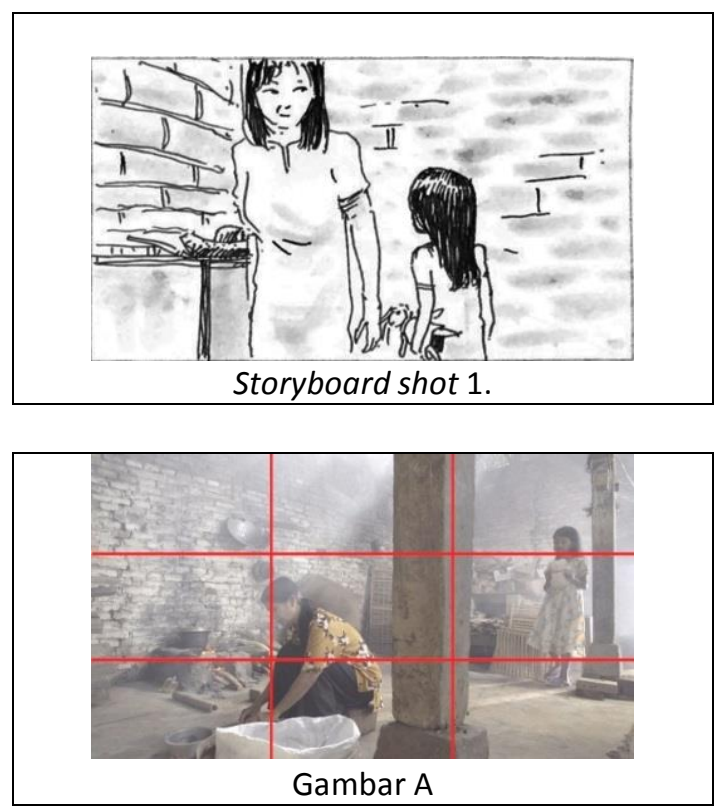

Gambar 11. Realisasi shot 1 pada Gambar A adegan Ibu dan Ratih Kecil berdasarkan storyboard di dalam scene 7. 


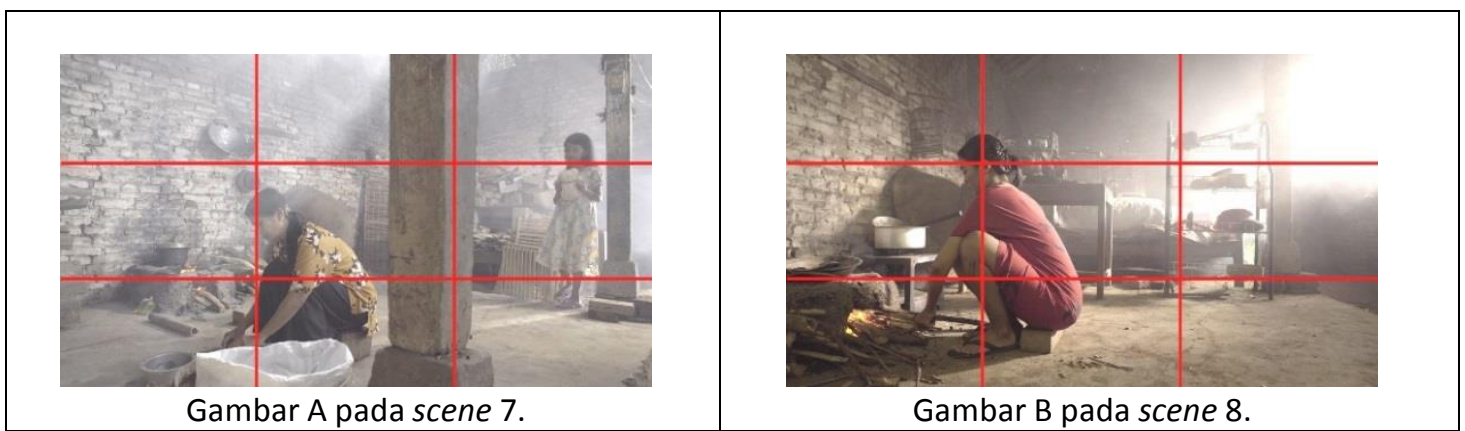

Gambar 12. Perbedaan suasana yang ditunjukan pada Gambar A dengan Gambar B.

Penempatan objek utama berada di kanan sekaligus kiri frame melalui garis perpotongan komposisi dinamik guna mendapatkan point of interest dalam komposisi gambar. Pergerakan kamera dalam bentuk paralaks digunakan pada shot gambar A yang ditunjukan melalui sudut serta arah adegan dengan tujuan menghasilkan dua latar belakang yang berbeda melalui gerakan aktivitas tokoh di dalam adegan (No Film School, 5 techniques that create depth and make your cinematography more dynamic). Perbedaan yang terdapat pada scene 7 dibanding scene 8 ditunjukan pada pengaplikasian teknik paralaks, di dalam scene 8 tidak menggunakan teknik pergerakan kamera. Penggunaan teknik deep focus pada master shot gambar A digunakan untuk menangkap ruang cerita pada komposisi gambar sehingga penonton dapat mengamati detail setiap elemen visual yang ada pada mise-enscene sebagai cara membangun visual storytelling di dalam scene 7 (Blain, 2011:54).

\section{KESIMPULAN}

Film "Asmaradana" merupakan realisasi dari realita kehidupan romansa yang terjadi di dalam hubungan suami istri dengan konflik utama berada pada trauma masa lalu Ratih yang harus dihadapi oleh tokoh Jaya, dihadirkan di dalam film melalui dominasi hubungan antar karakter tokoh dengan ditunjukan melalui rasa frustasi, depresi, kesepian, rasa penyesalan dan kesetiaan. Kesetiaan tersebut muncul di akhir suatu kejadian menjadi gambaran atau nilai positif untuk masyarakat tentang proses dalam menjalani hubungan suami istri. Sudut pandang Jaya sengaja dipilih di dalam film "Asmaradana" supaya penonton dapat ikut merasakan apa yang sebenarnya terjadi pada diri seorang suami yang memiliki seorang istri dengan trauma di masa lalunya.

Penggunaan komposisi dinamik pada film fiksi "Asmaradana" yang bertujuan untuk membangun visual storytelling dapat diterapkan dalam menyajikan konflik utama melalui hubungan antar karakter tokoh. Emosi 
atau kejadian yang dialami tiap karakter tokoh dapat tervisualisasikan dengan menempatkan posisi objek utama serta elemen-elemen visual ke dalam pembingkaian komposisi dinamik, sehingga konsep dominasi dan simbolisasi suasana serta emosi yang dirasakan tiap karakter tokoh dapat divisualisasikan dengan sangat baik. Penataan elemen-elemen visual pada pembingkaian komposisi gambar dapat menjadi bahasa visual yang menarik guna mendukung penceritaan film dan emosi tiap karakter tokoh. Ketika dominasi gambar dicapai melalui ukuran, jarak, penempatan dan posisi objek di dalam pembingkaian komposisi gambar, penonton dapat menonton tiap objek utama pada gambar sehingga ikut larut merasakan suasana serta emosi yang dialami oleh tokoh Jaya maupun tokoh Ratih.

\section{DAFTAR PUSTAKA}

Blain, Brown. 2011. Cinematography: theory and practice: image making for cinematographers and directors, USA: Focal Press.

Block, Bruce. 2008. The Visual Story: Creating The Visual Structure of Film, TV, and Digital Media, USA: Focal Press.

Bordwell, David. Kristin, Thompson. 2008. Film Art: An Introduction, Mc Graw - Hill Companies.
Caputo, Tony. 2003., Visual Storytelling: The Art and Technique, New York: Somerset.

Drever, James. Terjemahan Nancy Simanjuntak dari the penguin dictionary of psychology. 1998. Kamus Psikologi, Jakarta: Bina Aksara.

Effendy, Heru. 2014. Mari Membuat Film, Jakarta: Kepustakaan Populer Gramedia.

Fromm, Erich. 2005. The Art of Loving, Jakarta: Harper Perennial Modern Classics.

Harymawan, RMA. 1988. Dramaturgi, Bandung: Rosda.

Kartono, Kartini. 2009. Psikologi

Abnormal Dan Abnormalitas

Seksual, Mandar Maju.

Mascelli, A.S.C. Joseph V. 2010. Angle Kontiniti - Editing - Close up - Komposisi dalam

Sinematografi, Jakarta: FFTV IKJ.

Pratista, Himawan. 2008. Memahami

Film, Yogyakarta: Homerian

Pustaka.

Pratista, Himawan. 2017. Memahami

Film edisi Kedua, Yogyakarta:

Montase Film.

Rabiger, Michael. 2003. Directing Film

Techniques and Aesthetics, USA:

Focal Press.

Sugiarto, Atok. 2014. Color Vision:

Panduan Bagi Fotografer dalam 
Memahami dan Menggunakan

Warna, Jakarta: Kompas.

Thompson, Roy. 1998. Grammar of the

Shot: second edition, Woburn:

Focal Press.

Tim Penyusun Kamus, Pusat

Pembinaan dan Pengembangan

Bahasa. 1990. Kamus Besar

Bahasa Indonesia, Jakarta: Balai

Pustaka.

\section{Daftar Sumber Online}

Arief, R. Pribadi. Tekstur cahaya

Chiaroscuro dalam sinematografi.

Jakarta: SKKNI Sinematografer

Indonesia, 2014.

http://Sekolahfilm.com, diakses 5

Juni 2017.

Arief, R. Pribadi. Bahasa dalam

bingkai. Jakarta: SKKNI

Sinematografer Indonesia, 2014.

http://sekolahfilm.com, diakses 5

Juni 2017.

Eicar The International Film and

Television School Paris. Glossary.

http://www.eicar-

international.com/definition-visual-

storytelling.html, diakses 27 Juni

2017.

http://kesolo.com/macapat-asmaradana-

kekuatan-api-cinta.html, diakses 2

Januari 2018.

Kodak Cinematografi.

http://www.kodak.com/go/training.

html, diakses 5 Juni 2017.
Renne, V. 2014.

http://nofilmschool.com/2014/12/5-

techniques-create-depth- make-

cinematography-more-

dynamic.html, diakses 13

Desember 2016.

Simple, Developing and Complex Shots.

"Notes and Exercises." DFPR1101

Beth.https://sites.google.com/site/df

pr1101beth/projects-and-

exercises/07-sound-elements.com,

diakses 4 September 2017.

UKessays. Essays. Film Studies. "Visual

Storytelling in Films."

https://www.ukessays.com/essays/fi

lm-studies/visual-storytelling-in-

films.php, diakses 5 September

2017. 